\title{
ANALISIS PENERAPAN E-FILLING SEBAGAI UPAYA PENINGKATAN KEPATUHAN WAJIB PAJAK BADAN DALAM PENYAMPAIAN SPT TAHUNAN WAJIB PAJAK BADAN DI KPP PRATAMA PANDEGLANG
}

Oleh

Mohamad Husni

mohamadhusni06@gmail.com

Susi Susanti

Susisusantibb94@gmail.com

Universitas Bina Bangsa Banten

\begin{abstract}
In realizing modern tax administration system that the government provide an application that can be used for charging the taxpayer, reporting notification letter (SPT) is precise, fast, and secure. The purpose of this study was to analyze the implementation of efiling as an effort to increase tax compliance in the delivery of a notice (SPT) Annual taxpayer on STO Pandeglang. This study used a qualitative approach, by conducting a case study. by analyzing and understanding the issues related to tax compliance in the submission of their annual tax return taxpayer, analyze, investigate, and determine conclusions. Results of research showed there are some findings that an increase in the delivery of a notice (SPT) in 2015 and increased taxpayer compliance rate in $2015 . \quad$ It can be concluded that the implementation of e-filing can improve taxpayer compliance in the submission of annual returns taxpayers in KPP PRATAMA PANDEGLANG.
\end{abstract}

Keyword :Tax Compliance, e-filling

\section{PENDAHULUAN}

Peran penerimaan pajak sebagai sumber utama penerimaan negara Anggaran Pendapatan Belanja Negara (APBN) dalam menjungjung jalannya roda pemerintahan telah mendorong pihak Direktorat Jendral Pajak (DJP) sebagai lembaga yang ditujuk oleh pemerintah dalam menghimpun penerimaan pajak untuk melakukan reformasi perpajakan berupa penyempurnaan terhadap kebijakan perpajakan serta moderenisasi sistem administrasi perpajakan agar potensi penerimaan pajak yang tersedia dapat dipungut secara optimal dengan menjunjung asas keadilan sosial serta memberi pelayanan prima kepada wajib pajak. dalam pelaksanaan perpajakan, wajib pajak tidak memperoleh imbalan secara langsung atas pembayaran pajak yang dilakukanya. Wajib pajak diberi kepercayaan untuk menghitung, membayar, memperhitungkan, dan melaporkan sendiri besarnya pajak yang terhutang, sementara pihak fiskus diberi kewajiban untuk melakukan pegawasaan, pembinanaan, terhadap wajib pajak dalam melakukan kewajiban perpajakanya. Salah satu sektor umum dari pemerintahan indonesia yang memiliki peran vital khususnya menyangkut sumber penerimaan negara adalah Direktorat Jendral Pajak. Dalam rangka reformasi untuk meningkatkan penerimaan negara Direktorat Jendral Pajak melakukan sebuah terobosan guna meningkatkan pelayanan kepada wajib pajak yaitu dengan penerapan ICT. Melalui keputusan Direktorat Jendral Pajak No.kep-88/2004 secara resmi diluncurkan produk E-Filling atau elektronik filling system. E-Filling yaitu sistem penyampaian surat pemberitahuan (SPT) secara elektronik yang dilakuakan secara online dan real time melalui perusahaan penyedia jasa aplikasi yang ditujuk langsung oleh Direktorat Jendral Pajak. Pajak merupakan aspek yang penting dalam proses pembangunan suatu negara khususnya Indonesia, karena 
pembangunan bertujuan untuk mewujudkan serta meningkatkan kesejahtraan suatu negara. Peran pajak dalam hal ini adalah sebagai sumber pembiayaan dalam pembangunan di suatu negara, jadi dapat disimpulkan tanpa penerimaan pajak yang optimal maka proses pembangunan tidak akan berjalan dengan baik. Konsekuensi dari kondisi tersebut mengharuskan semua pihak terlibat dalam penyelenggaraan negara termasuk masyarakat sebagai wajib pajak. Keterlibatan tersebut merupakan kunci penting bagi negara dalam memacu roda pembangunan yang sedang dan akan berjalan. Kepatuhan wajib pajak dapat diidentifikasi dari kepatuhan wajib pajak dalam mendaftarkan diri, kepatuhan untuk menyetor kembali surat pemberitahuan (SPT), kepatuhan dalam perhitungan, dan pembayaran pajak terhutang, dan kepatuhan pembayaran tunggakan. Kepatuhan menjadi penting karena ketidakpatuhan secara bersamaan akan menimbulkan upaya penghindaran pajak, seperti tax avoidance, yang akan menimbulkan berkurangnya penyetoran dana pajak ke kas negara. Kantor Pelayanan Pajak Pratama Pandeglang baru memfasilitasi adanya e-filling untuk penyampaian SPT Tahunan Wajib Pajak Badan.

Jumlah Wajib Pajak Terdaftar, Realisasi SPT Tahunan, Rasio Kepatuhan Wajib Pajak Badan di Kantor Pelayanan Pajak Pratama Pandeglang

\begin{tabular}{lccc}
\hline \multicolumn{1}{c}{ Uraian } & $\mathbf{2 0 1 4}$ & $\mathbf{2 0 1 5}$ & $\mathbf{2 0 1 6}$ \\
\hline $\begin{array}{l}\text { Wajib Pajak Badan Yang } \\
\text { Terdaftar wajib SPT }\end{array}$ & 4.490 & 4.122 & 4.729 \\
$\begin{array}{l}\text { Realisasi Penyampaian SPT } \\
\text { dengan e-filling }\end{array}$ & 880 & 3.493 & 2.184 \\
$\begin{array}{l}\text { Rasio Kepatuhan Wajib Pajak } \\
\text { Badan }\end{array}$ & $2 \%$ & $85 \%$ & $46 \%$ \\
\hline
\end{tabular}

Sumber : Divisi Pengolahan Data dan Informasi KPP Pratama Pandeglang

Berdasarkan tabel diatas menunjukan bahwa untuk jumlah wajib pajak badan yang terdaftar, wajib SPT di tahun 2014 berjumlah 4.490 tahun 2015 berjumlah 4.122 kemudian di tahun 2016 berjumlah 4.729. sedangkan realisasi dari penyampaian SPT Tahunan Wajib Pajak Badan di tahun 2014 sebesar 880 dan tahun 2015 berjumlah 3.493 kemudian di tahun 2016 berjumlah 2.184. untuk rasio kepatuhan wajib pajak badan di tahun 2014 hanya 2\% kemudian di tahun 2015 mengalami peningkatan menjadi 85\% dan tahun 2016 sebesar 46\% penurunana ini mempengaruhi tingkat kepatuhan penyampaian SPT Tahunan Wajib Pajak Badan dalam penyampaian/ pelaporan SPT Tahunan di KPP Pratama Pandeglang.

\section{KAJIAN TEORITIK}

Kepatuhan Wajib Pajak

Menurut Mardiasmo (2011 : P.1) Pajak adalah iuran kepada kas negara berdasarkan undang-undang (yang dipaksakan) dengan tidak mendapat jasa timbal balik atau (kontraprestasi) yang langsung dapat ditunjuk dan yang gunanya untuk membayar pengeluaran umum. Menurut P.J.A Andriani dalam bukunya waluyo, (2014):2) Pajak adalah iuran kepada negara (yang dapat dipaksakan) yang terhutang oleh yang wajib membayarkannya menurut peraturan-peraturan umum ( undang-undang) dengan tidak mendapat prestasi kembali, yang langsung dapat ditunjuk dan yang gunanya adalah untuk membiayai pengeluaran-pengeluaran umum berhubungan dengan tugas negara yang menyelenggarakan pemerintahan. Dari kedua definisi diatas terdapat persamaan pandangan atau prinsip mengenai pajak. Perbedaaanya mengenai kedua bahasa atau kalimatnya saja. Kedua pendapat tersebut mempunyai unsur-unsur sebagai berikut: a). Pajak dipungut 
berdasarkan undang-undang. b). Tidak ada timbal balik (kontraprestasi) secara langsung. c). Dapat dipaksakan. d). Hasilnya untuk membiayai pembangunan

Jadi dapat disimpulkan bahwa pajak adalah iuran rakyat kepada negara( yang dipaksakan) yang terhutang oleh yang wajib membayarnya menurut peraturan-peraturan per undang-undangan dan tidak mendapat prestasi prestasi kembali yang langsung dapat ditunjuk. Kepatuhan wajib pajak adalah kemamuan dan kesadaran wajib pajak untuk memenuhi segala kewajiban perpajakanya. Pemerintah tentu mengharapkan agar moderenisasi yang berjalan ini mampu meningkatkan kepatuhan wajib pajak. Adanya peningkatan kepatuhan wajib pajak maka penerimaan negara dari sektor pajak dapat meningkat pula( jurnal Ita Salsalina Lingga, 2009, Pengaruh Modenisasi Sistem Administrasi Perpajakan Terhadap Kepatuhan Wajib Pajak Badan Pada KPP Pratama Bandung.(Universitas Kristen Maranatha:Vol.1 No.2 November 2009 ). Kepatuhan perpajakan merupakan ketaatan, tunduk dan patuh serta melaksanakan ketentuan perpajakan. Kepatuhan memenuhi kewajiban perpajakan secara sukarela merupakan tulang punggung sistem self assesment, dimana wajib pajak bertanggung jawab menetapkan sendiri kewajiban perpajakan dan kemudian secara akurat dan tepat waktu membayar dan melaporkan pajaknya sendiri.

Menurut Ita Salsalina Lingga dalam jurnalnya kepatuhan wajib pajak adalah suatu keadaan dimana wajib pajak memenuhi semua kewajiban perpajakanya dan melaksanakan hak perpajakanya, ada dua macam kepatuhan wajib pajak.

1. Kepatuhan formal : adalah suatu keadaan dimana wajib pajak memenuhi kewajiban perpajakaanya secara formal sesuai dengan undang-undang perpajakaan.

2. Kepatuhan material : yaitu sesuai dengan undang-undang perpajakan. Kepatuhan material dapat meliputi kepatuhan formal : wajib pajak yang memenuhi kepatuhan material adalah wajib pajak yang mengisi dengan jujur, lengkap, dan benar surat pemberitahuan (SPT) sesuai ketentuan penyampaiannya ke kantor pelayanan pajak sebelum batas waktu terakhir.

Dari kedua definisi Kepatuhan Wajib Pajak tersebut terdapat persamaan mengenai kedua bahasa dan kalimatnya saja. Perbedaanya menurut Sri Rahayu dalam jurnalnya menyebutkan kepatuhan wajib pajak adalah kemauan atau kesadaran wajib pajak untuk memenuhi kewajiban perpajaknya. Sedangakan menurut Ita Salsalin Lingga dalam jurnalnya menyebutkan bahwa Kepatuhan Wajib Pajak adalah wajib pajak memenuhi semua kewajiban perpajakanya dan melaksanakan hak perpajaknya. Jadi perbedaan kedua definisi di atas hanya terletak pada kedua bahasa dan kalimatnya saja. jadi dapat disimpulkan kepatuhan wajib pajak adalah kemauan dan kesadaran wajib pajak dalam memenuhi kewajiban perpajakanya dan melaksanakan hak perpajakan.

\section{Wajib Pajak}

Definisi wajib pajak menurut undang-undang Nomor. 28 Tahun 2007 pasal 1 ayat 2 adalah orang pribadi atau badan meliputi pembayaran pajak, pemotong pajak dan pemungut pajak yang mempunyai hak dan kewajiban perpajakaan sesuai dengan ketentuan peraturan perundang-undangan perpajakan. Wajib pajak dibedakan menjadi dua yaitu wajib pajak dalam negeri dan wajib pajak luar negeri.

\section{Kewajiban dan Hak Wajib Pajak}

Kewajiban wajib pajak menurut Mardiasmo : 1). Mendaftarkan diri untuk mendapatkan NPWP. 2). Melaporkan usahanya untuk dilakukan sebagai PKP. 3). Menghitung dan membayar pajak dengan benar. 4). Mengisi dengan benar SPT dan 
memaasukan ke kantor pelayanan pajak dalam batas waktu yang telah ditentukan. 6). Menyelenggarakan pembukuan/pencatatan. 7). Jika diperiksa wajib : a). Memperlihatkan dan meminjamkan buku atau catatan, dokumen yang menjadi dasarnya dan dokumen lain yang berhubungan dengan penghasilan yang diperoleh, kegiatan usaha, pekerjaan bebas wajib pajak atau objek terhutang pajak. b). Memberikan kesempatan untuk memasuki tempat atau ruangan yang dipandang perlu dan memberi bantuan guna kelancaraan pemeriksaan. 8). Apabila dalam waktu mengungkapkan pembukuan, pencatatan, atau dokumen serta keterangan yang diminta, wajib pajak terkait oleh suatu kewajiban untuk merahasiakan, maka kewajiban untuk merahasiakan itu ditindakan oleh pemerintah unttuk keperluan pemeriksaan.

\section{Hak-hak Wajib Pajak}

Adapun Hak Wajib Pajak adalah : 1). Mengajukan surat keberatan dan surat banding. 2). Menerima tanda bukti pemasukan SPT. 3). Melakukan pembetulan SPT yang telah dimasukan. 4). Mengajukan permohonan penundaan penyampaian SPT. 5). Mengajukan permohonan penundaan atau pengangsuran pembayaran pajak. 6). Mengajukan permohonan perhituangan pajak yang dikenakan dalm suarat ketetapan pajak. 7). Meminta pengembalian kelebihan pembayaran pajak. 8). Mengajukan permohonan penghapusan dan penggurangan sanksi serta pembetulan surat ketetapan pajak yang salah. 9). Memberi kuasa kepada orang untuk melaksanakaan kewajiban pajaknya. 10). Meminta bukti pemotongan atau pemungutan pajak. 11). Mengajukan keberatan atau banding

\section{Penerapaan $e$-filling}

e-filling adalah cara penyampaian SPT atau pemberitahuan perpanjangan SPT Tahunan yang dilakukan secara online dan real-time melalui website e-filing pajak DJP Online atau aplikasi yang disediakan ASP (Application Service Provider / Penyedia Jasa Aplikasi) pajak. e-filling menurut peraturan Direktorat Jendral Pajak Nomor 47/PJ/2008 pasal 1 ayat 7 adalah suatu cara penyampaian SPT dan penyampaian pemberitahuan perpanjangan SPT tahunan secara elektronik yang dilakukan secara online dan real time melalui jasa aplikasi. Surat Pemberitahuan (SPT) menurut peraturan Direktorat Jendral Pajak Nomor 47/PJ/2008 pasal 1 ayat 1 adalah surat yang oleh wajib pajak digunakan untuk melaporkan penghitungan dan/atau pembayaran pajak, objek pajak dan/atau bukan objek pajak, dan/atau harta dan kewajiban sesuai dengan ketentuan sesuai dengan peraturan perundang-undangan perpajakan. Sebelum adanya sistem administrasi perpajakn modern penyampaian SPT dilakukan secara langsung ke Kantor Pelayanan Pajak, namun setelah adanya sistem e-filling maka penyampaian SPT dapat dilakukan dari manapun serta kapanpun. System ini akan mempermudah para wajib pajak dalam penyampaian SPT, terlebih bagi para wajib pajak yang sedikit memiliki waktu luang. Adanya perkembangan teknologi informasi yang semakin canggih yang dalam hal ini ditandai dengan era digital menjadikan peluang sekaligus tantangan bagi DJP untuk senantiasa menyesuaikan diri. Guna Peningkatan Pelayanan kepada Wajib Pajak dalam hal penyampaian Surat Pemberitahuan (SPT), DJP mengembangkan e-SPT dan e-filling yang berbasis web. Hal tersebut memberikan banyak manfaat bagi Wajib Pajak di antaranya pelayanan yang lebih baik, terpadu, dan personal, melalui konsep One Stop Service yang melayani seluruh jenis pajak, sumber daya manusia yang lebih profesional karena telah terdapat fit and proper test dan competency mapping, pemeriksaan yang lebih terbuka dan profesional dengan konsep spesialisasi, adanya tenaga Account Representative (AR) yang bertugas membantu segala 
permasalahan wajib pajak, dan Pemanfaatan IT secara maksimal salah satunya melalui $e$ Filing (Abdurrohman et al., 2010).

e-filling merupakan program modernisasi yang dirancang untuk memanfaatkan IT secara maksimal. Menurut PER-01/PJ/2014, e-Filling adalah suatu cara penyampaian SPT Tahunan secara elektronik yang dilakukan secara online dan real time melalui internet pada website Direktorat Jenderal Pajak (www.pajak.go.id) atau Penyedia Jasa Aplikasi atau Applicatiom Service Provider (ASP)

Berikut adalah ketentuan Pelaporan SPT e-filling :

1) Penyampaian surat pemberitahuan secara elektronik dapat dilakukan 24 (dua puluh empat) jam sehari 7 (tujuh) hari seminggu dengan standar Waktu Indonesia Bagian Barat.

2) Surat pemberitahuan yang disampaikan secara elektronik pada akhir batas waktu penyampaian Surat Pemberitahuan yang jatuh pada hari libur, dianggap disampaikan tepat waktu.

3) Wajib Pajak mecetak dan menadatangani induk Surat Pemberitahuan yang telah diterima oleh Direktorat Jendral Pajak.

4) Wajib Pajak menyampaikan dokumen lainya yang wajib dilampirkan ke Kantor Pelayanan Pajak tempat Wajib Pajak terdaftar secara langsung atau melalui pos secara tercatat, paling lama:

a) 14 (empat belas) hari sejak batas terakhir Pelaporan Surat Pemberitahuan dalam hal Surat Pemberitahuan disampaikan sebelum batas akhir penyampaian

b) 14 (empat belas) hari sejak tanggal Penyampian Surat Pemberitahuan secara elektronik dalam hal Surat Pemberitahuan disampaikan setelah lewat batas akhir penyampaian. Meskipun wajib pajak sudah menyampaikan SPT nya melalui file yang sudah dikirim ke DJP sudah digitalisasi, tetapi hukum yang berlaku masih belum memperbolehkan "digital signature" atau tanda tangan digital diperbolehkan secara hukum, yang masih diakui keabsahanya adalah tanda tangan asli.

5) Dalam hal Wajib Pajak tidak menyampaikan dokumen lainya yang dipersyaratkan,Wajib Pajak dianggap tidak menyampaikan Surat Pemberitahuan.

6) Surat Pemberitahuan dianggap telah diterima dan tanggal penerimaan Surat Pemberitahuan sesuai dengan tanggal yang tercantum pada Bukti Penerimaan secara elektronik

7) Bukti Penerimaan seara elektrronik berisi informasi yang melipuuti Nomor Pokok Wajib Pajak, Tanggal, Jam, Nomor Transaksi Penyampian Surat Pemberitahuan (NTPS) dan Nomor Transaksi Pengiriman ASP (NTPA) serta nama Perusahaan Penyedia Jasa Aplikasi (ASP). ${ }^{1}$

8) Surat Pemberitahuan dianggap telah diterima dan tanggal yang tercantum

\section{Dasar Hukum e-filliing}

Peraturan Direktur Jendral Pajak Nomor Per 01/PJ/2014 tanggal 16 Januari 2014 Tentang Penyampaian Surat Pemberitahuan Tahunan dan Penyampian Pemberitahuan Perpanjangan Surat Pemberitahuan Tahunan secara elektronik (e-filling) melalaui website Direktorat Jendral Pajak (http://www.pajak.go.id Surat edaran Direktorat Jendral Pajak SE95/PJ/2011 Tentang Petunjuk teknis dan tata cara Penyampaian Surat Pemberitahuan bagi 
Wajib Pajak Orang Pribadi yang menggunakan formulir 1770S atau 1770SS secara e-filling melalui website Direktorat Jendral Pajak http://www.pajak.go.id

\section{Syarat Menggunakan $e$-filling}

Berdasarkan Peraturan Direktorat Jendral Pajak Nomor per-01/PJ/2004 untuk dapat menggunakan fasilitas e-filling Wajib Pajak harus memenuhi syarat-syarat sebagai berikut:

1. Sudah terdaftar sebagai Wajib Pajak (WP) atau sudah memiliki NPWP (Nomor Pokok Wajib Pajak)

2. Kartu identitas diri

3. Nomor telpon yang aktif agar segera dapat menerima SMS

4. Alamat e-mail

5. Dokumen yang digunakan untuk mengisi SPT

Memiliki PC memadai dan terkoneksi ke internet

Adapun syarat-syarat wajib pajak (WP) dapat menikmati layanan e-filling atau pengiriman data / penyampaian SPT secara elektronik adalah seperti berikut:

1. E-FIN yang diperoleh dari Kantor Pelayanan Pajak

2. Memilki aplikasi SPT dan submission data ke ASP laporanpajak.com.

\section{Surat Pemberitahuan (SPT)}

Surat pemberitahuan (SPT) adalah surat yang oleh wajib pajak digunakan untuk melaporkan penghitungan dan atau pembayaran pajak, objek pajak dan atau bukan objek pajak,dan/harta kewajiban sesuai dengan ketentuan peraturan perundang-undangan perpajakan. $^{2}$

\section{Batas Waktu Penyampaian SPT}

Batas waktu penyampaian surat pemberitahuan pajak adalah:

a. Untuk surat pembeitahuan massa, paling lama 20 (dua puluh) hari setelah akhir massa pajak. Khusus untuk surat pemberitahuan massa pajak pertambahan nilai disampaikan paling lama akhir bulan berikutnya setelah berakhirnya massa pajak.

b. Untuk surat pemberitahuan Tahunan Pajak Penghasilan Wajib pajak orang pribadi paling lama 3 (tiga ) bulan setelah akhir tahun pajak;Untuk surat pemberitahuan Tahunan Pajak Penghasilan wajib ajak badan, paling lama 4 (empat ) bulan setelah akhir tahun pajak. ${ }^{3}$

\section{METODE PENELITIAN}

Jenis metode penelitian yang digunakan adalah dengan menggunakan pendekatan kualitataif sedangkan metode penelitian yang digunakan adalah studi kasus yang dilakukan di KPP Pratama Pandeglang.

\section{Data dan Sumber Data}

Dalam penelitian ini data yang diperoleh adalah data kuantitatif dan kualitatif. Data kuantitatif berupa data statistik yang meliputi jumlah wajib pajak yang terdaftar dan jumlah penerimaan SPT tahunan periode 2014-2016 tetapi dalam hal ini Kantor Pelayanan Pajak Pratama Pandeglang baru memfasiltasi Penyampain SPT Tahunan wajib Pajak Badan dianalisis Tentang Penerapan E-filling Dalam Upaya Peningkatkan Kepatuhan Wajib Pajak 
Dalam Menyampikan SPT Tahunan Wajib Pajak Badan periode 2014-2016. Data yang digunakan dalam penelitian ini yaitu menggunakan data sekunder yaitu berupa data dokumentasi yang terdapat di Kantor Pelayanan Pajak Pratama Pandeglang periode 20142016.

\section{Teknik dan Pengumpulan Data}

Teknik pengumpulan data yang digunakan dalan penelitian ini adalah metode dokumentasi yang dilakuakan dengan mengumpulkan data sekunder dengan cara mencatat atau mengkopi dokumen-dokumen, arsip-arsip maupun data lain yang terkait dengan masalah yang ditelit Untuk memperoleh informasi dan data yang dikelola dalam penelitian ini, maka pengumpulan data dilakukan yaitu: Teknik Observasi, Teknik Wawancara Teknik Dokumentasi

\section{Prosedur Analisis Data}

Prosedur analisis data yang sesuai dengan penelitian ini adalah model Bogna dan Biklen. Menurut Bogna dan Biklen Analisis data kualitatif adalah proses secara sistematis mencari dan mengolah berbagai data yang bersumber dari wawancara, pengamatan lapangan, dan kajian dokumen (pustaka) untuk menghasilkan suatu laporan temuan penelitian. Pengertian tentang analisis data kualitatif tersebut telah sesuai dengan tahapan prosedur yang akan dilaksanakan penulis.

\section{HASIL PENELITIAN}

\section{Gambaran Umum Tentang Subjek Penelitian}

Sejarah berdirinya Kantor Pelayanan Pajak Pratama (KPP) Pratama Pandeglang, merupakan hasil perubahan dari Pajak Bumi dan Bangunan. Berdiri pada tanggal 29 Oktober 2004 silam pada kesempatan kali itu disahkan oleh Suharno, SH. MPM yang ketika itu beliau menjabat sebagai Direktur Pajak Bumi dan Bangunan (PBB) dan Bea Perolehan Hak Atas Tanah dan Bangunan (BPHTB) yang bertempat di J1. Mayor Widagdo No.6 Kebayan Pandeglang Banten 42213 yang sebelumnya bertempat di Jl. Sukarela No. 6 Pandeglang. Kantor Pelayanan Pajak (KPP) Pratama Pandeglang merupakan hasil dari pemisahan yang dilakukan oleh Kantor Pajak yang berasal dari wilayah Jawa Barat. Ketika masih berada di Jawa Barat, Banten yang saat ini sudah berpisah dan memisahkan diri dengan membentuk provinsi sendiri akhirnya memisahkan diri juga pada pelayanan pajak yang dahulu bernama Pajak Bumi dan Bangunan (PBB). Proses kerja yang dilakukan masih mengurusi kepentingan yang hanya berkutat pada masalah wajib pajak (WP) Pajak Bumi dan Bangunan dengan modal struktur yang masih sederhana, hal ini urusan yang mereka lakukanpun hanya pada satu konsentrasi masalah Pajak Bumi dan Banguna. Pada tanggal 1 juli 2007 nama instansi Pajak Bumi dan Bangunan (PBB) berubah menjadi Kantor Pelayanan Pajak Pratama Pandeglang yang sering dikenal dengan KPP Pratama Pandeglang yang telah berganti tempat di Jl. Mayor Widagdo No. 6 Kabayan Pandeglang Banten 42213. Dan jumlah pegawai yang ada di Kantor Pelayanan Pajak Pandeglang berjumlah 68 orang.

\section{Temuan Penelitian}

Kepatuhan wajib pajak merupakan pemenuhan kewajiban perpajakan yang dilakukan oleh pembayar pajak dalam rangka memberikan kontribusi bagi pembangunan negara ini yang diharapkan dalam pemenuhanya diberikan secara sukarela. Kepatuhan wajib pajak menjadi aspek penting mengingat sistem perpajakan di Indonesia menganut sistem self asessment dimana dalam prosesnya wajib pajak diberikan kepercayaan untuk menghitung, 
membayar dan melaporkan kewajiban perpajakanya sendiri. Untuk menganalisa Penerapan e-Filling dalam upaya Peningkatkan kepatuhan wajib pajak dalam penyampian Surat Pemberitahuan (SPT) Tahunan Wajib Pajak Badan pada Kantor Pelayanan Pajak Pratama Pandeglang penulis memperoleh data berupa data sekunder yaitu data yang diperoleh dari KPP Pratama Pandeglang berupa data statistik kepatuhan wajib pajak periode 2014-2016 sebagaimana gambar berikut ini. Untuk rasio kepatuhan wajib pajak badan di tahun 2014 hanya 2\% kemudian di tahun 2015 mengalami peningkatan menjadi 85\% peningkatan ini terjadi setelah adanya $e$-filling dengan adanya $e$-filling ini wajib pajak lebih mudah cepat dan aman dalam menyampaikan SPT Tahunanya, dan di tahun 2016 sebesar 46\% penurunana ini disebabkan menurunnya tingkat kesadaran penyampaian SPT Tahunan Wajib Pajak Badan. ${ }^{4}$

Namun angka tersebut tergolong kecil karena dari 157.193 wajib pajak yang terdaftar di KPP Pratama Pandeglang tidak seluruhnya menyampaikan (SPT) Tahunan Pajak Penghasilan $(\mathrm{PPh})$ setiap tahunnya. Penyampaian SPT sangat penting bagi negara terkait kepatuhan wajib pajak dalam pelaporan pembayaran pajak. Dari data statistik dapat disimpulkan bahwa pada kenyataanya proses untuk melakukan efisiensi kewajiban pajak melalui sistem e-fiiling ini tidak semudah yang di bayangkan. ini merupakan tugas bagi Kantor Pelayana Pajak Pratama Pandeglang untuk memberikan sanksi tegas terhadap wajib pajak yang tidak menyampaikan Surat Pemberitahuan (SPT) Tahunan guna meningkatkan kembali kepatuhan wajib pajak untuk melaksanakan kewajiban perpajakanya. Meningkatkan kembali kesadaran wajib pajak tentang pentingnya pajak bagi pembangunan di negeri ini. direktorat Jendral Pajak melakuakan sebuah terobosan baru yaitu sistem administrasi perpajkan yang lebih moderen yang memudahkan Wajib Pajak dalam menyampaikan SPTnya yaitu dengan megeluarkan sistem terbaru dalam penyampaian Surat Pemberitahuan (SPT) yaitu e-filling. e-fiiling diharapkan mampu meningkatkan Kepatuhan Wajib Pajak dalam melaporkan SPTnya. Temuan penelitian dalam sub fokus ini adalah :

1. Adanya peningkatan jumlah pelaporan Surat Pemberitahuan (SPT) Tahunan Wajib Pajak Badan di Tahun 2015 peningkatan ini terjadi setelah adanya e-filling dengan adanya e-filling wajib pajak lebih cepat aman dan efisien dalam melaporkan SPT Tahunanya.

2. Adanya penurunan pelaporan Surat Pemberitahuan (SPT) Tahuan wajib pajak badan di tahun 2016, penurunan ini terjadi karena turunnya tingkat kesadaran wajibb pajak dalam menyampaikan SPT Tahunanya hal ini di sebabkan kurang tegasnya penegakan hukum perpajakan atau sanksi perpajakan, wajib pajak dalam menyampaikan atau melaporkan SPT Tahunannya.

3. Adanya penurunana Kepatuhan Wajib Pajak Badan di KPP Pratama Pandeglang di tahun 2016 disebabkan oleh rendahnya kesadaran wajib pajak dalam melaporkan SPT Tahunannya, serta kondisi sistem administrasi perpajakan, akan tetapi pihak KPP Pratama Pandeglang selalu melakukan perbaikan pelayanan agar memotivasi wajib pajak dalam memenuhi kewajiban perpajakanya, kemudian sanksi perpajakan merupakan penyebab menurunya kepatuahan wajib pajak hal ini di karenakan kurangnya penegakan hukum perpajakan. Wajib pajak akan patuh jika adanya sanksi yang tegas kepada wajib pajak yang melanggar atau yang tidak melakukan kewajiban perpajakannya.

\section{PENUTUP}

Dari Analisi temuan dan pembahasan dalam penelitian ini peneulis memberikan kesimpulan sebagai berikut: E-filling merupakan program modernisasi yang dirancang untuk

${ }^{4}$ Arsip Dokumentasi KPP Pratama Pandeglang 
memanfaatkan IT secara maksimal. Menurut PER-01/PJ/2014, e-Filing adalah suatu cara penyampaian SPT Tahunan secara elektronik yang dilakukan secara online dan real time melalui internet pada website Direktorat Jenderal Pajak (www.pajak.go.id) atau Penyedia Jasa Aplikasi atau Applicatiom Service Provider (ASP). Dengan adanya penerapan e-filling pada KPP Pratama Pandeglang mampu meningkatkan penyampain Surat Pemberitahuan (SPT) Tahunan Wajib Pajak Badan, peningkatan tersebut terlihat dari jumlah Realisasi Pelaporan SPT di tahun 2015 mencapai 3.493 . Kepatuhan memenuhi kewajiban perpajakan secara sukarela merupakan tulang punggung sistem self assesment,yaitu sistem perpajakan yang dianut Indonesiadimana wajib pajak bertanggung jawab menetapkan sendiri kewajiban perpajakan dan kemudian secara akurat dan tepat waktu membayar dan melaporkan pajaknya sendiri. Peningkatan kepatuhan wajib pajak merupakan tujuan utama yang harus dilakukan KPP Pratama Pandegalang untuk meningkatkan kesadaran wajib pajak tentang pentingnya pajak bagi pembangunan negeri.penerapaan e-filling mampumeningkatkan rasio kepatuhan wajib pajak badan dalam penyampaian SPT tahunan pada KPP Pratama Pandeglang di tahun 2015 dengan persentase mencapai 85\% Dengan adanya e-filling Wajib Pajak lebih efisien cepat mudah dan aman dalam menyampaikan SPTnya. Setelah penulis menarik kesimpulan dari hasil penelitian, maka penulis merekomendasikan untuk penelitian selanjutnya peneliatian selanjutnya diharapkan dapat lebih diperluas lagi tidak hanya membahas mengenai penerapan e-filling sebagai upaya peningkatan kepatuhan wajib pajak dalam SPT tahunan wajib pajak badan, untuk menambah wawasan pengetahuan.

\section{DAFTAR PUSTAKA}

Arsip Dokumentasi KPP Pratama Pandeglang Rasio Kepatuhan Wajib Pajak Periode 20142015

Data Pokok APBN 20015. Laporan keuangan pemerintah pusat 2015 (Audit). Diakses Mei 2016.

Gusman Dwi Avianto.2016 Analisis peranan e-filling dalam rangka meningkatkan kepatuhan pelaporan surat pemberitahuan tahunan wajib pajk orang pribadi studi kasus pada kantor pelayanan pajak pratama malang selatan. Jurnal Perpajakan (JEJAK)Vol.9 No.1 2016

Ita Salsalina Lingga "Pengaruh penerapan e-SPT terhadap kepatuhan pajak. Jurnal Akutansi:/vol.5.No.1 mei 2013, hal 50-56, ISSN:8698

Keputusan Menteri Keuangan Repulik Indonesia. 2000. Keputusan Menteri Keuangan Nomor 544/KMK.O4/2000 yang diubah dengan Keputusan Menteri Keuangan Nomor 235/KMK.03/2000

Monita Pantreysih Dauhan, David Paul Elia Sareang, Robert Lambey. 2015. Analisis Kepatuhan Wajib Pajak Badan Berdasarkan Realisasi Penerimaan Pajak Penghasilan Badan. ( Jurnal Berkala Ilmiah Efisiensi Volume 15 Nomor.04. Tahun 2015. 
Nurul Citra Noviandini. 2012 Pengaruh persepsi kebermanfaatan,persepsi kemudahaan penggunaan,dan kepuasan wajib pajak terhadap penggunaan e-filling bagi wajib pajak. (Jurnal Nominal/Volume 1 Nomor 1/Tahun 2012

Resmi,Siti. 2011. Perpajakan Teori dan Kasus. Jakarta Selatan: Salema Empat

Rahayu,Sri,Salsalina,Ita,Lingga.2009. Pengaruh moderenisasi sistem administrasi perpajakan terhadap kepatuhan wajib pajak. Jurnal Akuntansi /Vol.5 NO.1 Mei 2013, hal 5056,ISSN: 2085.8698.

Undang-undang Nomor.28 tahun 2007 pasal 1 ayat. tentang ketentuan umum dan tata cara perpajakan.

Peraturan Direktorat Jendral Pajak. 2014 . Peraturan Direktorat Jendral Pajak Nomor PER 01/PJ/2014 Penyampaian Surat Pemberitahuan Tahunan dan Penyampaian Pembeitahuan Perpanjangan Surat Pemberitahuan Melalui Website DJP.

www.barusaja.com/24/11/2016 Target Penerimaan Pajak KPP Pratama Pandeglang www.pajaktakesblogspot.o.id Diakses pada /2008/12/28 Wajib Pajak Patuh www.Pajak.go.id Sanksi administrasi atas keterlambatan atau tidak menyampaikan SPT .

Diakses 08 Febuari 2014

www.pajak.com/Laporan Keuangan Pemerintah Pusat Tahun 2015 (Audit)

www.pajak.co.id Strategi meningkatkan keppatuhan wajib pajak Diakses 4 juli 2012

www.Pajak.go.id Upaya Peningkatan kepatuhan wajib pajak. Diakses 6 juli 2012 